\title{
PEMAHAMAN KONSEP GRUP MAHASISWA CALON GURU MATEMATIKA DENGAN KEMAMPUAN MATEMATIKA TINGGI
}

\author{
Agnita Siska Pramasdyahsari', Maya Rini Rubowo² \\ 1,2 Pendidikan Matematika Universitas PGRI Semarang \\ aghrathalita@gmail.com¹, mayarinirubowo@gmail.com²
}

\begin{abstract}
Abstrak
Penelitian ini bertujuan untuk mendeskripsikan tentang pemahaman konsep grup pada mahasiswa calon guru matematika dengan kemampuan matematika tinggi. Penelitian ini merupakan penelitian deskriptif kualitatif, dengan subjek penelitian mahasiswa calon guru matematika yang telah mendapatkan mata kuliah teori grup. Subjek penelitian dipilih yang sesuai dengan kriteria dengan kemampuan matematika tinggi dilihat dari tes kemampuan matematika, memiliki kemampuan komunikasi yang baik dan mampu menjelaskan dengan baik. Pengumpulan data dilakukan melalui pemberian tes pemahaman konsep grup yang dilanjutkan dengan wawancara. Tes tertulis dan wawancara dilakukan dua kali untuk keperluan triangulasi data melalui triangulasi waktu. Kesimpulan dari pembahasan dapat dituliskan bahwa subjek dengan kemampuan matematika tinggi dapat mendefinisikan dan menunjukkan suatu grup memenuhi sifat-sifat secara detail dan terperinci.
\end{abstract}

Kata kunci: pemahaman konsep, grup, kemampuan matematika tinggi

\begin{abstract}
The study aims to describe the understanding of group concepts in prospective mathematics teacher with high mathematical abilities. This research is a descriptive qualitative research, with a research subject is a prospective mathematics teacher who have taken group theory courses. The subjects were selected according to the criteria of having high mathematical abilities based on mathematical ability tests, having good communication skills and being able to explain. Data collection was carried out through providing group concept understanding tests followed by interviews. Written tests and interviews were conducted twice for the purposes of triangulating data through time triangulation. Regarding to the discussion section, it can be summarized that subjects with high mathematical abilities can define and show a group fulfilling the traits in detail.
\end{abstract}

Keywords: understanding of concepts, groups, high mathematical ability 
Agnita Siska Pramasdyahsari

Pemahaman Konsep Grup Mahasiswa Calon Guru Matematika dengan Kemampuan

Matematika Tinggi

\section{PENDAHULUAN}

Pemahaman adalah salah satu aspek penting dalam prinsip pembelajaran matematika (NCTM, 2000). Oleh karena itu, proses belajar matematika harus diikuti dengan pemahaman siswa yang merupakan tujuan utama dari belajar matematika. Kemampuan pemahaman pada siswa ditandai dengan adanya kemampuan dalam menyusun makna dari pesan yang disampaikan dalam proses pembelajaran baik melalui komunikasi lisan, tulisan maupun grafik (Anderson, Krathwohl \& Bloom, 2000).

Hiebert and Carpenter (1992) mendeskripsikan pemahaman sebagai koneksi antara kepingan-kepingan informasi yang ada. Pemahaman juga didefinisikan sebagai kemampuan untuk membuat koneksi antara skema yang telah ada dalam pikiran seseorang dengan skema yang ada pada informasi (Pramasdyahsari, 2014). Sedangkan pemahaman konseptual melibatkan kemampuan untuk membuat koneksi antara interpretasi yang berbeda dan pemahaman tentang kesamaan dan perbedaan antara beragam interpretasi (Cathcart, Pothier, Vance, \& Bezuk, 2006).

Sebagai mahasiswa calon guru matematika, penguasaan konsep matematika tingkat lanjut dan kompleks sangat penting. Melalui penguasaan konsep matematika tersebut yang diperoleh salah satunya melalui mata kuliah teori grup diharapkan mahasiswa memiliki mathematical knowledge for teaching (Ball, Thames, \& Phelps, 2008) yang mumpuni. Sehingga, penting bagi mahasiswa calon guru matematika untuk mempunyai pemahaman konseptual yang baik. Selain itu, diharapkan mahasiswa mampu mengembangkan algoritma berpikir yang runtut dan logis melalui pembuktian teorema, serta menggunakan konsep yang mereka dapatkan di perguruan tinggi sebagai bekal ketika mengajar matematika sekolah.

Salah satu mata kuliah yang dapat membekali mahasiswa calon guru matematika dengan kemampuan tersebut adalah teori grup. Findel (2001) mendefinisikan aljabar abstrak (teori grup dan teori ring) sebagai generalisasi dari aljabar sekolah. Berdasarkan hal tersebut dapat ditarik benang merah adanya keterkaitan antara teori grup dengan aljabar sekolah. Sehingga diharapkan dengan pemahaman konseptual pada teori grup yang baik dapat mendukung pembelajaran di matematika sekolah khususnya pada bidang aljabar. Selain itu, mata kuliah ini juga mengenalkan mahasiswa calon guru matematika tentang konsep matematika secara terstruktur dan memberikan kesempatan bagi mereka untuk memahami struktur sistem bilangan (Dubinsky, Dautermann, Leron, \& Zazkis, 1994). Gallian (1994) menyatakan bahwa struktur aljabar (teori grup dan teori ring) penting dalam pendidikan untuk melatih seseorang berpikir secara matematis. Istilah dan metodologi dalam struktur aljabar sering digunakan dalam komputer sains, fisika, kimia dan komunikasi data, sehingga struktur aljabar memegang peranan yang 
sangat penting. Dalam penelitian Murray, Baldinger, Wasserman, Broderick, \& White (2017) mengidentifikasi pentingnya struktur aljabar bagi guru matematika sekolah menengah yaitu mengkaitkan pendekatan, konten matematika, dan prinsip-prinsip untuk mengkomunikasikan relevansi matematika tingkat lanjut kepada siswa. Secara spesifik dalam Wasserman (2016) mengidentifikasi topik-topik dalam struktur aljabar terkait dengan pengajaran konsep sifat-sifat aritmatika, invers, struktur himpunan, dan solusi persamaan. Akan tetapi, sebagian besar mahasiswa calon guru matematika menganggap mata kuliah teori grup sulit karena terlalu abstrak dan sulit menemukan koneksi dengan topik di matematika sekolah. Hal ini dikuatkan oleh Titova (1998) bahwa konsep dari struktur aljabar (teori grup dan teori ring) tidak dapat dipelajari tanpa contoh konkret dan masalah yang melekat dengan konsep tersebut. Meskipun demikian, para mahasiswa calon guru matematika mampu mengidentifikasi koneksi matematika sekolah dengan struktur aljabar yang fokus pada teori ring secara eksplisit meskipun masih terbatas (Pramasdyahsari, Setyawati, \& Albab, 2019). Hal ini mendorong peneliti untuk mencari solusi dalam membantu mahasiswa untuk memahami konsep teori grup dengan lebih baik sehingga mahasiswa mampu membuat koneksi matematika yang ada dan melihat kebermanfaatan bagi matematika sekolah. Untuk dapat membantu mahasiswa agar dapat memahami konsep grup dengan lebih baik dalam pembelajaran, maka diperlukan informasi mengenai deskripsi pemahaman konsep mahasiswa calon guru matematika dengan jenjang kemampuan matematika yang berbeda. Sehingga ke depan mampu dipersiapkan desain pembelajaran mata kuliah dengan lebih tepat.

Berdasarkan latar belakang di atas, perlu adanya pengungkapan profil pemahaman konsep grup untuk mengidentifikasi pemahaman konsep-konsep dasar yang berperan penting dalam pembelajaran matematika sekolah. Akan tetapi, dalam artikel ini hanya fokus pada bahasan mahasiswa dengan kemampuan matematika tinggi.

\section{METODE PENELITIAN}

Penelitian ini merupakan penelitian deskriptif kualitatif yang mendeskripsikan dengan jelas dan terperinci tentang pemahaman konsep grup mahasiswa calon guru matematika dengan kemampuan matematika tinggi. Pemilihan subjek penelitian didasari beberapa kriteria sebagai berikut: (1) telah mengambil mata kuliah teori grup, (2) memiliki kemampuan matematika tinggi berdasarkan tes kemampuan matematika dengan mempertimbangkan variable gender (laki-laki dan perempuan) sebagai variable pembatas, dan (3) memiliki komunikasi yang baik dan kemampuan menyampaikan pendapat. 
Agnita Siska Pramasdyahsari

Pemahaman Konsep Grup Mahasiswa Calon Guru Matematika dengan Kemampuan

Matematika Tinggi

Instrumen utama dalam penelitian ini adalah peneliti sendiri, seperti yang disampaikan dalam Moleong (2007) bahwa peneliti yang memahami secara menyeluruh kondisi di lapangan. Sedangkan instrumen pendukung dalam penelitian ini meliputi (a) Tes Kemampuan Matematika (TKM) yang berisi soal tentang materi prasyarat konsep grup; (b) Tes Pemahaman Konsep Grup (TPKG) yang berisi dua buah soal pembuktian yang disusun berdasarkan indikator pemahaman konsep grup; (c) Pedoman Wawancara untuk menggali informasi yang tidak termuat dalam TPKG dengan teknik wawancara berbasis tugas; (d) Alat Bantu Rekaman untuk merekam dan mengambil gambar selama proses penelitian berlangsung.

Triangulasi yang digunakan dalam penelitian ini adalah triangulasi waktu yaitu teknik dilakukan untuk menguji kredibilitas data dengan cara melakukan pengecekan dengan wawancara, observasi atau teknik lain dalam waktu atau situasi yang berbeda (Sugiyono, 2012). Pada penelitian ini, triangulasi dilakukan dengan membandingkan data hasil wawancara tugas 1 dengan data hasil wawancara tugas 2 pada waktu yang berbeda. Jika keduanya menunjukkan kecenderungan yang sama maka data tersebut dikatakan kredibel. Jika tidak, maka diberikan tugas 3 dengan masalah yang ekuivalen dengan masalah 1 dan masalah 2. Data hasil wawancara tugas 3 kemudian dibandingkan dengan data hasil wawancara dua tugas sebelumnya untuk menentukan data yang ekuivalen dan diambil sebagai data penelitian yang akan dianalisis. Jika data dari ketiga masalah tersebut tidak ada yang menunjukkan kecenderungan yang sama dengan keduanya, maka diberikan tugas lagi kemudian dibandingkan dengan data-data sebelumnya. Kegiatan tersebut dilakukan berulang-ulang sampai diperoleh data yang kredibel yaitu dua data yang menunjukkan kecenderungan yang sama.

Analisis data dilakukan berdasarkan hasil pekerjaan tertulis subjek penelitian dan hasil wawancara dengan cara mengorganisasikan data ke dalam kategori, menjabarkan kedalam unit-unit yang penting dan membuat kesimpulan sehingga mudah dipahami oleh diri sendiri atau orang lain (Sugiyono, 2008). Analisis dilakukan secara mendalam pada mahasiswa tentang pemahaman konsep grup. Proses analisis data dimulai dengan menelaah seluruh data yang tersedia dari tes tertulis maupun wawancara (Moleong, 2007). Cara mereduksi data (yaitu kegiatan yang mengacu pada proses pemilihan, pemusatan perhatian, penyederhanaan, pengabstraksian dan transformasi data mentah di lapangan), memaparkan data (meliputi pengklasifikasi dan identifikasi data, yaitu menuliskan kumpulan data yang terorganisir dan terkategori sehingga memungkinkan untuk menarik kesimpulan dari data tersebut), dan menarik kesimpulan dari data yang telah dikumpulkan dan memverifikasi kesimpulan tersebut (Miles dan Huberman, 2008). 
Agnita Siska Pramasdyahsari

Pemahaman Konsep Grup Mahasiswa Calon Guru Matematika dengan Kemampuan

Matematika Tinggi

\section{HASIL DAN PEMBAHASAN}

Penelitian ini bertujuan untuk mengetahui pemahaman konsep mahasiswa pendidikan matematika dalam mata kuliah teori grup tentang konsep Grup.

\section{Pengambilan Data 1}

Sifat Tertutup

\begin{tabular}{l} 
1.) Jelas $Q^{+} \neq \phi, \exists \frac{a b}{2} \in Q^{+}$. \\
dilengkapi operasi biner *. \\
Ads $\left(Q^{+}, *\right)$ grup. \\
Jaudb: \\
\hline 1.) Adb Tertutup \\
Ambil sbr $a, b \in Q^{+}$. \\
$a * b=\frac{a b}{2}($ definis $)$. \\
karena $a, b \in Q^{+}$jelas $a b \in Q^{+}$ \\
(diturunkan dr sifat ferfutap $R)$ \\
\hline maka $\frac{a b}{2} \in Q^{+}$. \\
Jadi $\left(Q^{+}, *\right)$ Tertutup.
\end{tabular}

Gambar 1 Jawaban Subjek untuk Sifat Tertutup pada Pengambilan Data 1

$P \quad:$ Bagaimana menyelediki suatu himpunan merupakan suatu grup?

$S$ : Pertama himpunan tersebut bukan himpunan kosong, dalam hal ini terdapat $\frac{a . b}{2}$ yang merupakan elemen dari himpunan rasional positif. Selanjutnya punya operasi biner, memiliki sifat tertutup, bersifat assosiatif, memiliki elemen identitas dan setiap elemennya memiliki invers.

$P \quad: \quad$ Oke, kemudian bagaimana menunjukkan sifat tertutup?

$S$ : Saya ambil sebarang dua elemen berbeda anggota bilangan rasional positif, misalkan a dan b, kemudian akan saya tunjukkan dengan operasi biner yang diberikan bahwa $a^{*} b=\frac{a . b}{2}$ menurut definisi yang diberikan dalam soal. Karena a dan b anggota dari bilangan rasional positif maka hasil kali a dan b juga elemen bilangan rasional positif yang diturunkan dari sifat tertutup bilangan real pada operasi perkalian.

$P \quad: \quad B a i k$, ada lagi yang ingin ditambahkan?

$S$ : Sudah, Bu.

Berdasarkan hasil tes dan wawancara terlihat bahwa subjek penelitian dapat menjelaskan dengan baik sifat tertutup pada perkalian bilangan rasional positif yang diturunkan dari sifat tertutup perkalian pada sistem bilangan real 
Agnita Siska Pramasdyahsari

Pemahaman Konsep Grup Mahasiswa Calon Guru Matematika dengan Kemampuan

Matematika Tinggi

dengan penjelasan yang detail di setiap langkah penjelasan. Namun tidak menyebutkan bahwa ada $\frac{1}{2}$ yang juga merupakan elemen dari bilangan rasional positif.

\section{Sifat Asosiatif}

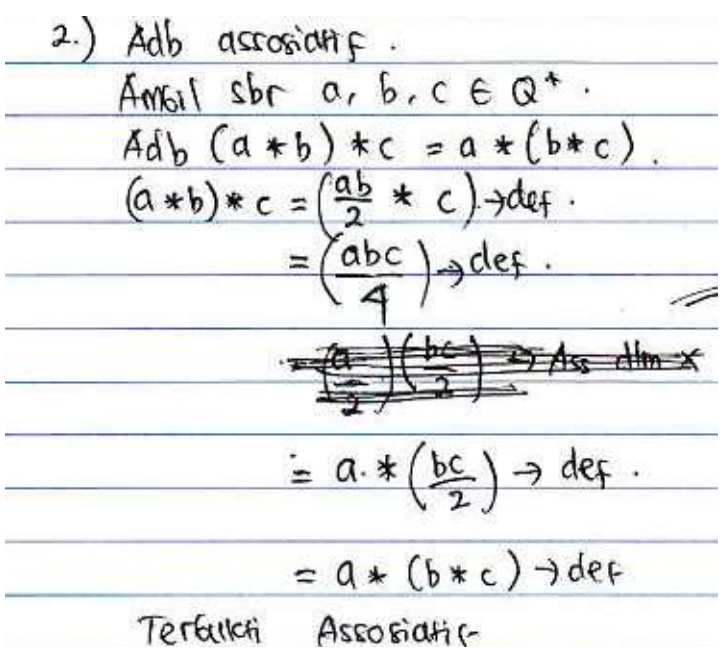

Gambar 2 Jawaban Subjek untuk Sifat Asosiatif pada Pengambilan Data 1

$P \quad$ : Selanjutnya bagaimana menunjukkan bahwa himpunan tersebut memenuhi sifat assosiatif?

$S \quad$ : Saya ambil sebarang $a, b$ dan $c$ elemen bilangan rasional positif, kemudian akan saya tunjukkan apakah $\left(a^{*} b\right)^{*} c=$ $a^{*}\left(b^{*} c\right)$.

$P \quad:$ Bagaimana menunjukkannya?

$S \quad$ : Dari ruas kiri saya uraikan menggunakan definisi operasi biner bintang yang diberikan dalam soal. Hingga diperoleh hasil yang sudah tidak berupa operasi biner, selanjutnya saya bentuk sehingga membentuk operasi biner pada ruas kanan dan terbukti ruas kiri sama dengan ruas kanan. Jadi memenuhi sifat assosiatif.

Berdasarkan hasil tes dan wawancar, subjek dapat menguraikan ruas kiri menjadi ruas kanan untuk menunjukkan sifat assosiatif dengan memberikan penjelasan sifat yang melekat dalam setiap langkah dan melakukan manipulasi bentuk operasi tanpa merubah nilai. 
Agnita Siska Pramasdyahsari

Pemahaman Konsep Grup Mahasiswa Calon Guru Matematika dengan Kemampuan

Matematika Tinggi

\section{Memiliki Elemen Identitas}



Gambar 3 Jawaban Subjek untuk Elemen Identitas pada Pengambilan Data 1

$P \quad$ : Bagaimana menentukan elemen identitas?

$S \quad$ : Saya ambil sembarang sebuah elemen di himpunan, misalkan a. Setelah itu saya misalkan elemen identitas dalam himpunan tersebut adalah $i$ maka $a^{*} i=i^{*} a=a$. Kemudian dari $a^{*} i=a$ dengan menggunakan definisi operasi biner, kemudian kedua ruas dikalikan 2 dan $\frac{1}{a}$ diperoleh $i=2$, dimana 2 merupakan elemen bilangan rasional positif. Jadi memenuhi sifat memiliki elemen identitas.

Berdasarkan hasil tes dan dan wawancara, subjek dapat menentukan elemen identitas yang juga merupakan elemen dari himpunan bilangan rasional positif dengan penjelasan yang jelas dan detail dari setiap langkah yang dilakukan.

\section{Setiap elemen memiliki invers}

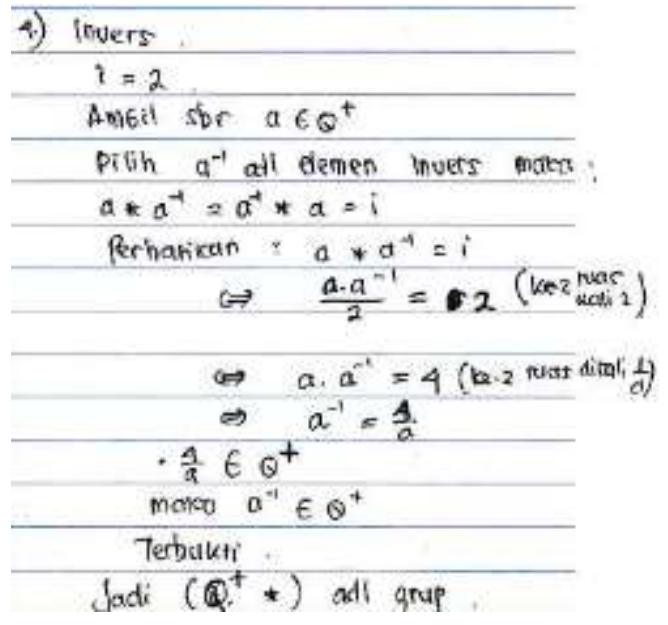

Gambar 4 Jawaban Subjek untuk Invers pada Pengambilan Data 1

$P \quad:$ Bagaimana menunjukkan bahwa setiap elemen memiliki invers? 
Agnita Siska Pramasdyahsari

Pemahaman Konsep Grup Mahasiswa Calon Guru Matematika dengan Kemampuan Matematika Tinggi

$S \quad$ : Pada langkah sebelumnya telah diketahui identitas dalam himpunan ini adalah 2. Kemudian saya ambil sembarang a elemen dari bilangan rasional positif. Selanjutnya saya pilih $a^{-1}$ sebagai inver dari a. Sehingga diperoleh $a^{*} a^{-1}=a^{-1} * a=i$. Dari $a^{*} a^{-1}=1$ saya kalikan kedua ruas dengan 2 kemudian $\frac{1}{a}$ hingga diperoleh $\frac{4}{a}$ yang merupakan elemen bilangan rasional positif. Jadi dapat disimpulkan bahwa setiap elemen dalam himpunan memiliki invers.

$P \quad$ : Baik apa yang dapat disimpulkan dari setiap langkah yang sudah ditunjukkan?

$S \quad$ : Karena bilangan rasional positif bukan himpunan kosong dan memiliki satu operasi biner dan memenuhi sifat tertutup, assosiatif, memiliki elemen identitas dan setiap elemennya memiliki invers, maka merupakan suatu grup.

Berdasarkan hasil tes dan wawancara, subjek penelitian dapat dengan runtut menentukan invers elemen dengan menggunakan elemen identitas yang telah ditentukan pada langkah sebelumnya. Subjek dapat menjelaskan dengan urut dan detail langkah-langkah untuk menentukan invers elemen dan menunjukkan bahwa invers tersebut juga merupakan elemen dari himpunan bilangan rasional positif. Subjek juga dapat menyimpulkan bahwa himpunan tersebut merupakan suatu grup dengan menyebutkan secara terperinci definisi grup secara menyeluruh.

\section{Pengambilan Data 2}

\section{Sifat Tertutup}

1.) Adb Tertutup
Ambal sebarang $a, b \in R$
$a * b=a+b+a b \Rightarrow$ Desinisi
karena $a, b \in R$ maka $a \cdot b \in R \quad$ (dari sfat maktutup perikation bil. real)
karena $a, b, a b \in R \quad b+a b \in R$
shg $a * b=a+b+a b \in R$.
Jadi Terbuki $(R, *)$ Terutup.

Gambar 5 Jawaban Subjek untuk Sifat Tertutup pada Pengambilan Data 2

$P \quad:$ Bagaimana menyelediki suatu himpunan merupakan suatu grup?

$S$ : Pertama himpunan tersebut bukan himpunan kosong, punya operasi biner, bersifat tertutup, assosiatif, memiliki elemen identitas dan setiap elemennya memiliki invers. 
Agnita Siska Pramasdyahsari

Pemahaman Konsep Grup Mahasiswa Calon Guru Matematika dengan Kemampuan Matematika Tinggi

$P \quad: \quad$ Oke, kemudian bagaimana menunjukkan sifat tertutup?

$S$ : Saya ambil sebarang dua elemen berbeda anggota bilangan real, misalkan a dan $b$, kemudian akan saya tunjukkan dengan operasi biner yang diberikan bahwa $a^{*} b=a+b+a b$ menurut definisi yang diberikan dalam soal. Karena a dan $b$ anggota dari bilangan real maka hasil kali a dan b juga elemen bilangan real sehingga $a+b+a b$ juga anggota bilangan real. Jadi memenuhi sifat tertutup.

Berdasarkan hasil Subjek penelitian dapat menuliskan dan menjelaskan sifat tertutup dengan baik. Selain itu juga mampu menjelaskan hasil operasi dari operasi biner yang dikerjakan merupakan elemen dari himpunan bilangan riil.

\section{Sifat Assosiatif}

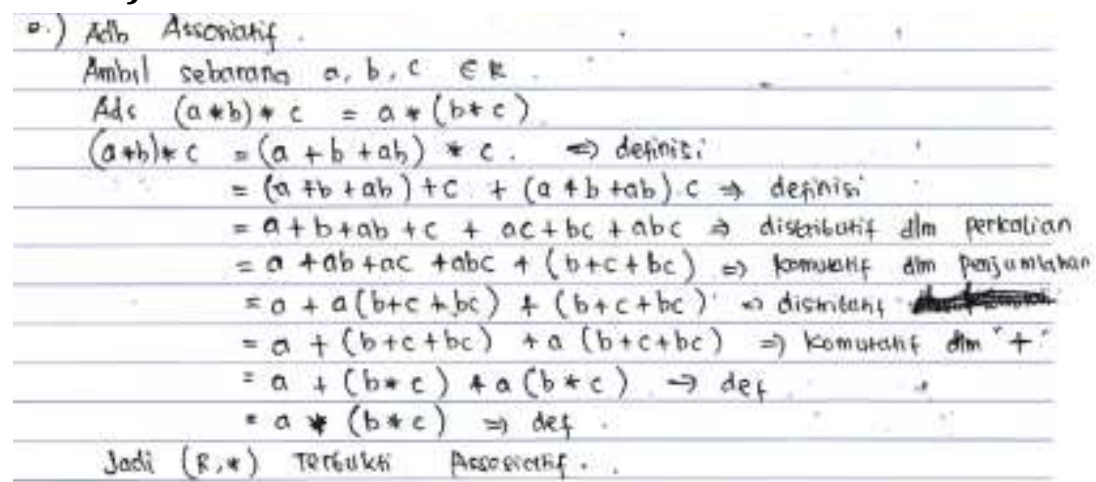

Gambar 6 Jawaban Subjek untuk Sifat Asosiatif pada Pengambilan Data 2

$P \quad:$ Selanjutnya bagaimana menunjukkan bahwa himpunan tersebut memenuhi sifat assosiatif?

$S$ : Saya ambil sebarang $a, b$ dan $c$ elemen bilangan real, kemudian akan saya tunjukkan apakah $\left(a^{*} b\right)^{*} c=a^{*}\left(b^{*} c\right)$.

$P$ : Bagaimana menunjukkannya?

$S$ : Dari ruas kiri saya uraikan menggunakan definisi operasi biner bintang yang diberikan dalam soal. Hingga diperoleh hasil yang sudah tidak berupa operasi biner, selanjutnya saya bentuk sehingga membentuk operasi biner pada ruas kanan dan terbukti ruas kiri sama dengan ruas kanan. Jadi memenuhi sifat assosiatif.

Berdasarkan hasil tes dan wawancara, subjek penelitian menuliskan terlebih dahulu sifat assosiatif. Kemudian membuktikannya dari ruas kiri ke ruas kanan dengan langkah yang detail dengan menyebutkan sifat yang digunakan dalam setiap langkah. Subjek menjelaskan secara terperinci dan benar-benar memahami definisi operasi biner dalam soal sehingga subjek dapat melakukan manipulasi objek agar membentuk operasi biner yang dimaksudkan. 
Agnita Siska Pramasdyahsari

Pemahaman Konsep Grup Mahasiswa Calon Guru Matematika dengan Kemampuan Matematika Tinggi

\section{Memiliki Elemen Identitas}

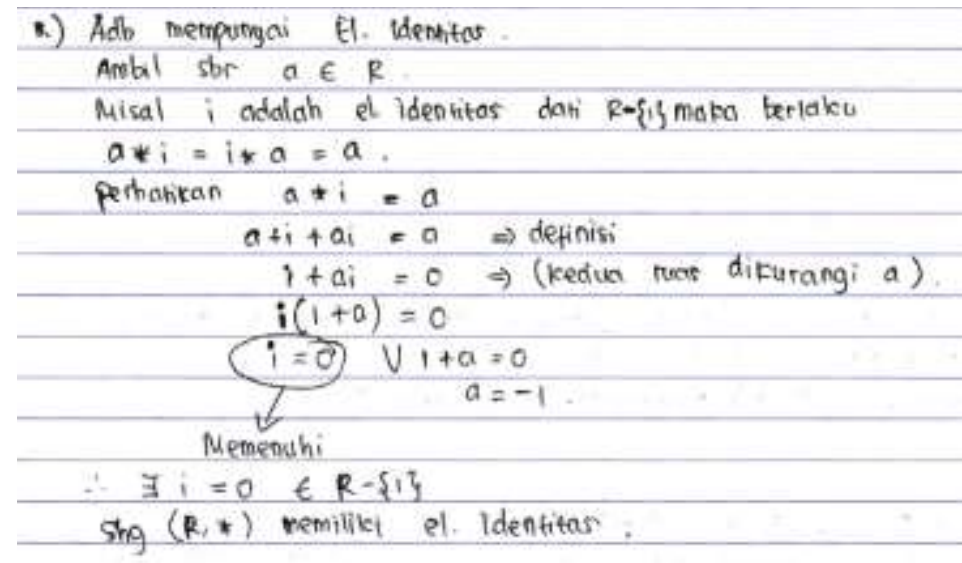

Gambar 7 Jawaban Subjek untuk Elemen Identitas pada Pengambilan Data 2

$P \quad:$ Bagaimana menentukan elemen identitas?

$S$ : Saya ambil sembarang sebuah elemen di himpunan, misalkan a. Setelah itu saya misalkan elemen identitas dalam himpunan tersebut adalah i maka $a^{*} i=i^{*} a=a$. Kemudian dari $a^{*} i=a$ dengan menggunakan definisi operasi biner. Selanjutnya, kedua ruas dikurangi a hingga ditemukan i=0 yang merupakan elemen bilangan real tanpa nol.

Berdasarkan hasil tes dan wawancara, subjek penelitian mengerjakan dengan sistematis dimulai dengan menuliskan dan menunjukkan memiliki elemen identitas. Selanjutnya tiap langkah diperkuat dengan sifat yang yang digunakan. Subjek juga mampu menentukan elemen identitas tersebut sesuai dengan syarat yang diberikan.

\section{Setiap elemen memiliki invers elemen}

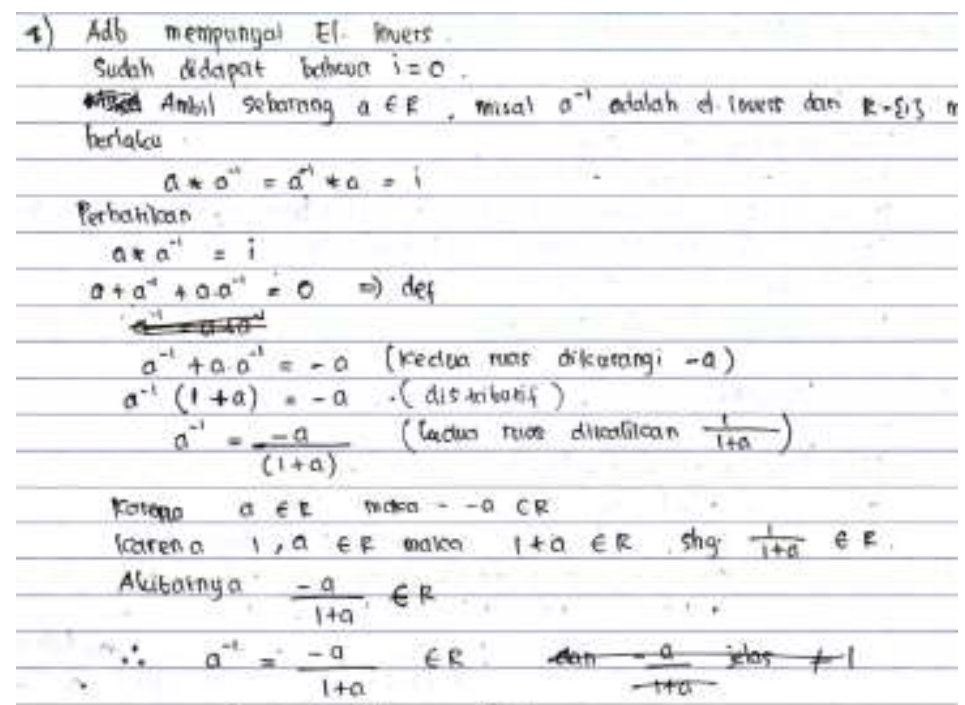

Gambar 8 Jawaban Subjek untuk Invers pada Pengambilan Data 2 
Agnita Siska Pramasdyahsari

Pemahaman Konsep Grup Mahasiswa Calon Guru Matematika dengan Kemampuan

Matematika Tinggi

$P \quad: \quad B a g a i m a n a$ menunjukkan bahwa setiap elemen memiliki invers?

$S$ : Pada langkah sebelumnya telah diketahui identitas dalam himpunan ini adalah 0. Kemudian saya ambil sembarang a elemen dari bilangan real. Selanjutnya saya pilih $a^{-1}$ sebagai invers dari a. Sehingga diperoleh $a^{*} a^{-1}=a^{-1 *} a=i$. Dari $a^{*} a^{-1}=0$ saya uraikan menurut definisi dalam soal. Kedua ruas saya kurangi dengan a. Selanjutnya dengan menggunakan sifat pengelompokkan dan mengalikan kedua ruas dengan $\frac{1}{1+a}$ diperoleh $a^{-1}=\frac{-a}{1+a}$. Karena a elemen $R$ maka - a juga elemen $R .1$ elemen $R$ maka $1+a$ juga elemen $R$. Sehingga $\frac{-a}{1+a}$ juga elemen $R$. Jadi dapat disimpulkan bahwa setiap elemen dalam himpunan memiliki invers.

$P \quad: \quad$ Baik apa yang dapat disimpulkan dari setiap langkah yang sudah ditunjukkan?

$S$ : Karena bilangan real bukan himpunan kosong dan memiliki satu operasi biner dan memenuhi sifat tertutup, assosiatif, memiliki elemen identitas dan setiap elemennya memiliki invers, maka merupakan suatu grup.

Berdasarkan hasil tes dan wawancara, subjek penelitian sudah mampu mengkaitkan antara elemen identitas yang diperoleh dalam langkah sebelumnya untuk menentukan invers elemen. Subjek juga dengan lancar menunjukkan langkah untuk menentukan invers elemen untuk setiap anggota dan memastikan invers tersebut juga merupakan anggota dari himpunan. Selanjutnya, subjek juga dapat menyimpulkan bahwa himpunan yang diselidiki merupakan grup dengan mengulangi kembali definisi yang telah dipenuhi.

Tabel 1 Triangulasi Data

\begin{tabular}{|c|c|c|}
\hline Indikator & Data 1 & Data 2 \\
\hline $\begin{array}{l}\text { Menjelaskan } \\
\text { sifat tertutup }\end{array}$ & $\begin{array}{l}\text { Berdasarkan hasil tes dan } \\
\text { wawancara subjek dapat } \\
\text { menguraikan ruas kiri } \\
\text { menjadi ruas kanan untuk } \\
\text { menunjukkan sifat assosiatif } \\
\text { dengan memberikan } \\
\text { penjelasan sifat yang melekat } \\
\text { dalam setiap langkah dan } \\
\text { melakukan manipulasi } \\
\text { bentuk operasi tanpa } \\
\text { merubah nilai. }\end{array}$ & $\begin{array}{l}\text { Berdasarkan hasil subjek } \\
\text { dapat menuliskan dan } \\
\text { menjelaskan sifat tertutup } \\
\text { dengan baik. Selain itu juga } \\
\text { mampu menjelaskan hasil } \\
\text { operasi dari operasi biner } \\
\text { yang dikerjakan merupakan } \\
\text { elemen dari himpunan } \\
\text { bilangan riil. }\end{array}$ \\
\hline $\begin{array}{l}\text { Menje } \\
\text { sifat a }\end{array}$ & $\begin{array}{llr}\text { Berdasarkan hasil tes dan } \\
\text { wawancara subjek dapat } \\
\text { menguraikan ruas kiri }\end{array}$ & $\begin{array}{l}\text { Berdasarkan hasil tes dan } \\
\text { wawancara, } \\
\text { menuliskan terlebih dahulu }\end{array}$ \\
\hline
\end{tabular}


menjadi ruas kanan untuk menunjukkan sifat assosiatif dengan memberikan penjelasan sifat yang melekat dalam setiap langkah dan melakukan manipulasi bentuk operasi tanpa merubah nilai.

sifat assosiatif. Kemudian membuktikannya dari ruas kiri ke ruas kanan dengan langkah yang detail dengan menyebutkan sifat yang digunakan dalam setiap langkah. Subjek menjelaskan secara terperinci dan benarbenar memahami definisi operasi biner dalam soal sehingga subjek dapat melakukan manipulasi objek agar membentuk operasi biner yang dimaksudkan.

\begin{tabular}{llr}
\hline $\begin{array}{l}\text { Menjelaskan } \\
\text { sifat elemen }\end{array}$ & Berdasarkan hasil tes dan \\
identitas & dan wawancara subjek dapat \\
& menentukan & elemen \\
& identitas yang & juga \\
& merupakan elemen dari \\
& himpunan bilangan rasional \\
& positif dengan penjelasan \\
& yang jelas dan detail dari \\
& setiap langkah \\
& dilakukan. yang
\end{tabular}

Berdasarkan hasil tes dan wawancara subjek mengerjakan dengan sistematis dimulai dengan menuliskan dan menunjukkan memiliki elemen identitas. Selanjutnya tiap langkah diperkuat dengan sifat yang yang digunakan. Subjek juga mampu menentukan elemen identitas tersebut sesuai dengan syarat yang diberikan.

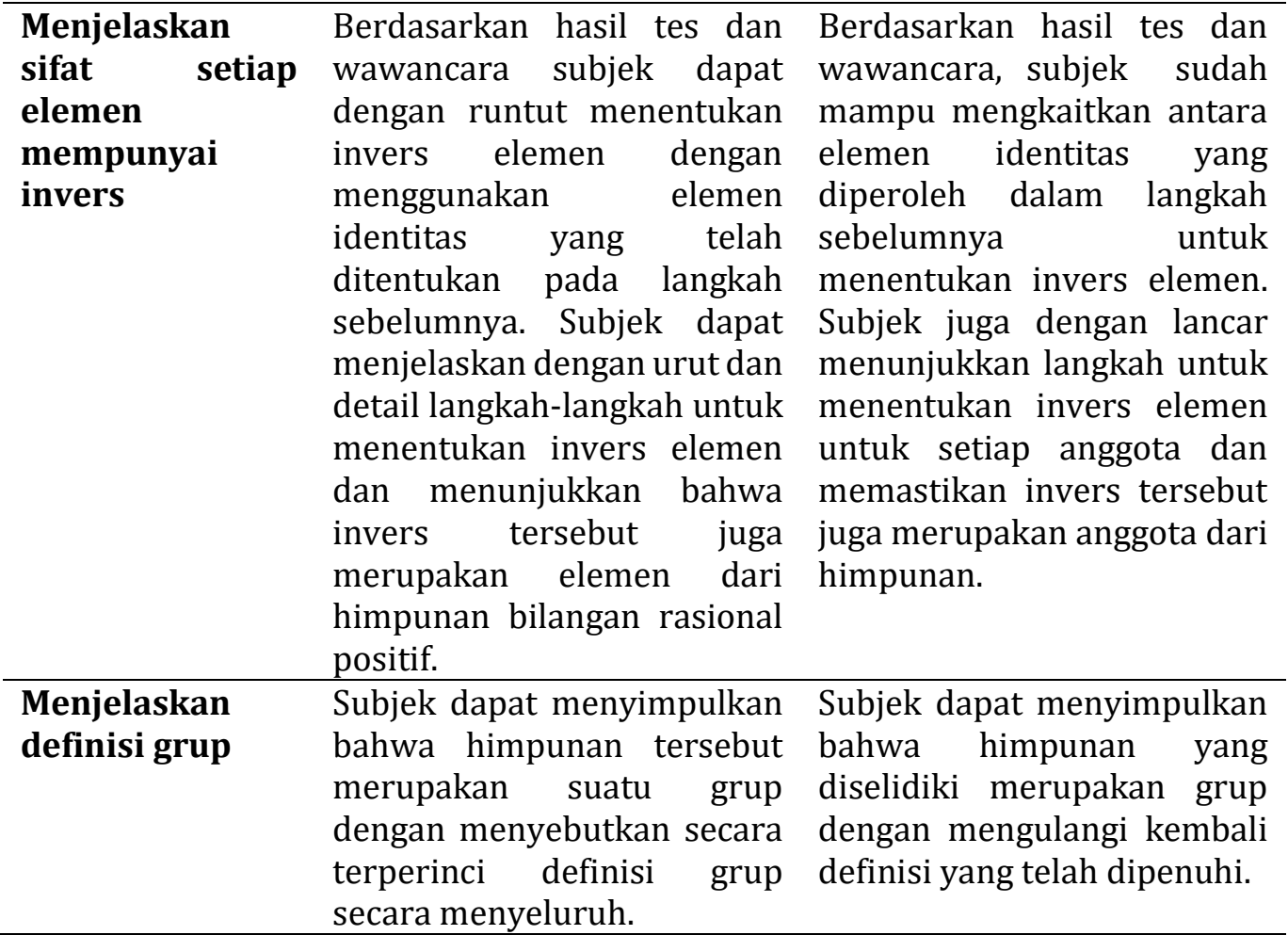


Agnita Siska Pramasdyahsari

Pemahaman Konsep Grup Mahasiswa Calon Guru Matematika dengan Kemampuan

Matematika Tinggi

Berdasarkan hasil dari triangulasi data dapat diperoleh kesimpulan bahwa subjek dapat mendefinisikan suatu grup secara detail dan terperinci dimulai dengan himpunan yang tak kosong, memiliki operasi biner kemudian menunjukkan satu persatu sifat tertutup, bersifat assosiatif, memiliki elemen identitas serta menunjukkan bahwa setiap elemen memiliki invers dengan menggunakan sifat-sifat yang melekat di dalam operasi.

\section{KESIMPULAN DAN SARAN}

Berdasarkan hasil penelitian dan pembahasan dapat disimpulkan bahwa subjek dengan kemampuan matematika tinggi dapat mendefinisikan dan menunjukkan suatu grup memenuhi sifat-sifat secara detail dan terperinci. Berdasarkan hasil tersebut dapat menjadi pertimbangan bagi dosen pengampu dalam menentukan strategi pembelajaran yang dapat memfasilitasi mahasiswa sesuai dengan keragaman kemampuan matematika di kelas, saah satunya dalam hal ini adalah mahasiswa dengan kemampuan matematika tinggi. Sedangkan bagi mahasiswa, mereka dapat melakukan penilaian diri untuk menentukan strategi belajar yang tepat dalam mata kuliah teori grup.

\section{DAFTAR RUJUKAN}

Anderson, L.W., Krathwohl, D.R, \&, Bloom, S. (2001). A Taxonomy for Learning Teaching and Assessing. New York: Longman.

Ball, D. L., Thames, M. H., \& Phelps, G. (2008). Content knowledge for teaching: What makes it special? Journal of Teacher Education, 59(5), 389-407. doi:10.1177/0022487108324554.

Cathcart, W. G., Pothier, Y., Vance, J. H., \& Bezuk, N. S. (2006). Learning Mathematics in Elementary and Middle Schools: A Learner-Centred Approach. Upper Saddle River: Pearson Prentice Hall.

Dubinsky, E., Dautermann, J., Leron, U., \& Zazkis, R. (1994). On learning fundamental concepts of group theory. Educational Studies in Mathematics; an International Journal, 27(3), 267-305. doi:10.1007/BF01273732.

Findell, B. R. (2001). Learning and Understanding in Abstract Algebra. Unpublished, PhD Thesis. University of New Hampshire.

Gallian, J. A. (1994). Contemporary Abstract Algebra (3 ${ }^{\text {rd }}$ edition). Lexington, MA: D. C. Heath.

Hiebert, J., \& Carpenter, T.P. (1992). Learning and teaching with understanding. In D.A. Grouws (Ed.), Handbook of research on mathematics teaching and learning (pp. 65-100). New York: Macmillan.

Miles dan Huberman. (2008). Qualitative Data Analysis. London: SAGE Publications. 
Agnita Siska Pramasdyahsari

Pemahaman Konsep Grup Mahasiswa Calon Guru Matematika dengan Kemampuan

Matematika Tinggi

Moleong, Lexy J. (2007). Metodologi Penelitian Kualitatif. Bandung: Remaja Rosdakarya Offset.

Murray, E., Baldinger, E., Wasserman, N., Broderick, S., \& White, D. (2017). Connecting advanced and secondary mathematics. Issues in the Undergraduate Mathematics Preparation of School Teachers, 1. Retrieved from https://digitalcommons.montclair.edu/mathsci-facpubs/4

NCTM. (2000). Principle and Standards for School Mathematics. Reston VA: NCTM.

Pramasdyahsari, A.S. (2014). The Profile of Primary School Students' Conceptual Understanding of Equivalent Fractions Based on Kolb's Learning Styles. Thesis: Universitas Negeri Surabaya.

Pramasdyahsari, A.S., Setyawati, R., \& Albab, I. (2019). Connecting university mathematics and school mathematics to address Klein's double discontinuity: A case of ring theory. Beta: Jurnal Tadris Matematika, 12(2), 122-132. https://doi.org/10.20414/betajtm.v12i2.336.

Sugiyono. (2008). Metode Penelitian Pendidikan Pendekatan Kuantitatif, Kualitatif, dan R\&D. Bandung: Alfabeta.

Sugiyono. (2012). Memahami Penelitian Kualitatif. Bandung: Alfabeta.

Titova. (1998). Understanding Abstract Algebra Concepts. Becker College.

Wasserman, N. H. (2016). Abstract algebra for algebra teaching: Influencing school mathematics instruction. Canadian Journal of Science, Mathematics and Technology Education, 16(1), 28-47. Doi:10.1080/14926156.2015.1093200. 